\title{
The effects of glycine, glutamate and their combination on cardiodynamics, coronary flow and oxidative stress in isolated rat hearts
}

\author{
Ivan Srejovic MD¹, Vladimir Jakovljevic MD PhD¹, Vladimir Zivkovic MD PhD", Nevena Jeremic Mr Pharm², \\ Maja Jevdjevic $\mathrm{MD}^{3}$, Isidora Stojic Mr Pharm², Dragan Djuric MD PhD ${ }^{4}$
}

I Srejovic, V Jakovljevic, V Zivkovic, N Jeremic, M Jevdjevic, I Stojic, D Djuric. The effects of glycine, glutamate and their combination on cardiodynamics, coronary flow and oxidative stress in isolated rat hearts. Curr Res Cardiol 2015;2(2):63-68.

OBJECTIVES: To examine the effects of glycine, glutamate and their combination on cardiac function, coronary flow and oxidative stress in isolated rat hearts, and to examine the effects of potential activation of $N$-methyl-Daspartate (NMDA) receptors in isolated rat hearts.

METHODS: The hearts of male Wistar albino rats were excised and perfused according to the Langendorff technique, and cardiodynamic parameters (maximum rate of pressure development in the left ventricle $[\mathrm{dp} / \mathrm{dt}$ max]; minimum rate of pressure development in the left ventricle $[\mathrm{dp} / \mathrm{dt}$ min], systolic left ventricular pressure, diastolic left ventricular pressure, heart rate) and coronary flow were determined during the subsequent administration of glycine, glutamate and their combination. Oxidative stress biomarkers, including thiobarbituric acid-reactive substances, nitrites $\left(\mathrm{NO}_{2}^{-}\right)$, superoxide anion radical $\left(\mathrm{O}_{2}^{-}\right)$and hydrogen peroxide $\left(\mathrm{H}_{2} \mathrm{O}_{2}\right)$, were each determined spectrophotometrically in coronary venous effluent.

$\mathrm{T}$ he $N$-methyl-D-aspartate (NMDA) receptor belongs to the group of ionotropic glutamate receptors. Functional NMDA receptors are tetramers composed of two obligatory glycine-binding subunits (GluN1), and two GluN2 and/or GluN3 subunits. The GluN2 subunit binds glutamate, while the GluN3 subunit binds glycine (1,2). NMDA receptors containing GluN1/GluN2 subunits require two molecules of glycine and two molecules of glutamate for activation, which act as coagonists, while NMDA receptors composed of GluN1/GluN3 subunits requires the presence of glycine only $(3,4)$. The NMDA receptor acts as an ion channel for cations $\left(\mathrm{Na}^{+}, \mathrm{K}^{+}\right.$and $\left.\mathrm{Ca}^{2+}\right)$; however, its permeability for $\mathrm{Ca}^{2+}$ is 10 times higher compared with $\mathrm{Na}^{+}$(5). Unlike $\alpha$-amino-3-hydroxy-5methyl-4-isoxazole propionate (AMPA) receptors and kainate receptors, which also belong to the ionotropic glutamate receptor family, NMDA receptors are characterized by certain unique properties such as strong voltage-dependent block by $\mathrm{Mg}^{2+}$, slow gating kinetics and the abovementioned high permeability for $\mathrm{Ca}^{2+}(6)$. NMDA receptors play a crucial role in the functioning of the nervous system and, under physiological conditions, mediate functions such as learning and memory; they also play a role in glutamate excitotoxicity, which is involved in stroke, epilepsy, traumatic brain injury and neurodegerative disorders including Huntington's disease and Alzheimer's disease (7-9). Besides the nervous system, NMDA receptors are found in other tissues, including in the heart; specifically, some NMDA receptor subunits have been found in rat cardiomyocytes $(10,11)$. The presence and activity of NMDA receptors in heart tissue was demonstrated by several studies in which NMDA receptor antagonists were applied $(12,13)$; however, their role in the

\begin{abstract}
RESULTS: Treatment with glycine and glutamate alone did not cause a statistically significant change in any of the observed parameters; however, their combined administration induced significant decreases in $\mathrm{dp} / \mathrm{dt} \max , \mathrm{dp} / \mathrm{dt}$ min, heart rate and coronary flow compared with the control conditions. Treatment with glycine and glutamate together induced significant increases in $\mathrm{NO}_{2}^{-}, \mathrm{O}_{2}^{-}$and $\mathrm{H}_{2} \mathrm{O}_{2}$ levels. After the washout period, all parameters that had changed (cardiodynamic parameters, coronary flow and levels oxidative stress biomarkers) returned to values that were not significantly different from controls.

CONCLUSIONS: The results of the present study indicate that NMDA receptors likely have important roles in the function of the heart and coronary circulation. In addition, these results are suggestive of a damaging effect of NMDA receptor overstimulation in heart functioning, potentially mediated by oxidative stress.
\end{abstract}

Key Words: Cardiodynamics; Glutamate; Glycine; N-methyl-D-aspartate receptor; Oxidative stress

regulation of physiological functions of the cardiovascular system has, to date, not been elucidated. NMDA receptors are also located on endothelial cells in the blood vessels of the central nervous system (CNS) as well in other tissues such as the lungs, heart, aorta and mesenteric artery (14-17).

The presumed mechanism of glutamate excitotoxicity is $\mathrm{Ca}^{2+}$ overload due to prolonged stimulation of NMDA receptors; in addition, the proposed mechanism of the adverse effect of homocysteine is activation of NMDA receptors and increase in $\mathrm{Ca}^{2+}$ concentration in the cells (18). The increased $\mathrm{Ca}^{2+}$ level affects the functioning of mitochondria and results in mitochondrial metabolic dysfunction, which is reflected in disturbances in the production of ATP, fatty acid oxidation, neurotransmitter biosynthesis and regulation of $\mathrm{Ca}^{2+}$ homeostasis (19). Mitochondria can take up $\mathrm{Ca}^{2+}$, which is present in higher concentrations in the cell; this results in increased production of oxidative/nitrosative species that may damage the mitochondria and the cell $(19,20)$. Mitochondrial dysfunction may lead to the release of apoptosis factors into cytosol and cause the activation of downstream effectors of caspase-3, resulting in cardiomyocyte apoptosis (18). Furthermore, NMDA receptor activation, increased levels of $\mathrm{Ca}^{2+}$ and lowered energy metabolism due to mitochondrial dysfunction trigger consequent endothelial and neuronal nitric oxide synthase (NOS) activation (these both being calcium-dependent enzymes), leading to increased nitric oxide (NO) and peroxynitrite levels and feeding back into the mitochondrial cascade and ATP depletion (21).

Considering that glutamate and glycine act as a NMDA receptor coagonists, it would be of interest to assess their mutual influence on the myocardium, particularly the coronary circulation. Therefore, the

${ }^{1}$ Department of Physiology; ${ }^{2}$ Department of Pharmacy, Faculty of Medical Sciences, University of Kragujevac, Kragujevac; ${ }^{3}$ College of Health Studies in

Cuprija, Cuprija; ${ }^{4}$ Institute of Medical Physiology "Richard Burian", Faculty of Medicine, University of Belgrade, Belgrade, Serbia

Correspondence: Prof. Vladimir Lj. Jakovljevic, Department of Physiology, Faculty of Medical Sciences, University of Kragujevac, Serbia.

Telephone 381-34-342944, e-mail drvladakgbg@yahoo.com 
aim of the present study was to examine the effects of glycine, glutamate and their combination on cardiac function, coronary flow (CF) and oxidative stress in isolated rat hearts, and to examine the effects of potential activation of NMDA receptors in isolated rat hearts.

\section{Isolated rat heart preparation}

\section{METHODS}

The hearts of male Wistar albino rats (total $n=36 ; n=12$ rats per experimental group [discarded hearts were not included in the total number of hearts]) were excised and perfused using a Langendorff apparatus (Experimetria Ltd, Hungary). The rats were eight weeks of age and had a body mass between $180 \mathrm{~g}$ and $200 \mathrm{~g}$. The rats were obtained from the Military Medical Academy, Belgrade, Serbia. After anesthesia with ketamine $(10 \mathrm{mg} / \mathrm{kg})$ and xylazine $(5 \mathrm{mg} / \mathrm{kg})$, the animals were euthanized via cervical dislocation (Schedule 1 of the Animals/Scientific Procedures Act, 1986, United Kingdom). Following a rapid thoracotomy and cardiac arrest by superfusion with ice-cold isotonic saline, the hearts were promptly excised and attached to the Langendorff apparatus via aortic cannulation. The hearts were retrogradely perfused under a constant perfusion pressure of $70 \mathrm{cmH}_{2} \mathrm{O}$ with complex Krebs-Henseleit solution composed of the following: $\mathrm{NaCl} 118 \mathrm{mmol} / \mathrm{L}, \mathrm{KCl} 4.7 \mathrm{mmol} / \mathrm{L}, \mathrm{CaCl}_{2} \cdot 2 \mathrm{H}_{2} \mathrm{O} 2.5 \mathrm{mmol} / \mathrm{L}$, $\mathrm{MgSO}_{4} \cdot 7 \mathrm{H}_{2} \mathrm{O} 1.7 \mathrm{mmol} / \mathrm{L}, \mathrm{NaHCO}_{3} 25 \mathrm{mmol} / \mathrm{L}, \quad \mathrm{KH}_{2} \mathrm{PO}_{4}$ $1.2 \mathrm{mmol} / \mathrm{L}$, glucose $11 \mathrm{mmol} / \mathrm{L}$ and pyruvate $2 \mathrm{mmol} / \mathrm{L}$, equilibrated with $95 \% \mathrm{O}_{2}$ plus $5 \% \mathrm{CO}_{2}$ at $37^{\circ} \mathrm{C}(\mathrm{pH} 7.4)$.

Following the restoration of normal rhythm, a sensor (transducer BS4 73-0184, Experimetria Ltd, Hungary) was placed in the left ventricle through an incision in the left atrium adjacent to a severed mitral valve for continuous monitoring of cardiac function.

\section{Experimental protocol}

The hearts from all three experimental groups underwent a 25 min stabilization period. During this period, each of the hearts was subjected to short-term occlusion (20 s) followed by simultaneous bolus injections of $5 \mathrm{mmol} / \mathrm{L}$ adenosine $(60 \mu \mathrm{L}$ at a flow of $10 \mathrm{~mL} / \mathrm{min}$ to elicit maximal $\mathrm{CF})$ to test coronary vascular reactivity. If CF did not increase by $100 \%$ compared with control values, the hearts were disposed of. CF was determined flowmetrically. Once CF was stabilized (three measurements of the same value), samples of coronary effluent were collected (control values) and the experimental protocol was initiated. Hearts were perfused with either $100 \mu \mathrm{mol} / \mathrm{L}$ glycine, $100 \mu \mathrm{mol} / \mathrm{L}$ glutamate or $100 \mu \mathrm{mol} / \mathrm{L}$ glycine $+100 \mu \mathrm{mol} / \mathrm{L}$ glutamate .

Each of the substances was administered for $5 \mathrm{~min}$, followed by a washout period lasting for $10 \mathrm{~min}$. Samples of coronary effluent were collected in the final minute of substance application (effect) and in the final minute of the washout period (washout). Using the sensor within the left ventricle, the following parameters of myocardial function were determined: maximum rate of pressure development in the left ventricle (dp/dt max); minimum rate of pressure development in the left ventricle (dp/dt min); systolic left ventricular pressure; diastolic left ventricular pressure; and heart rate (HR).

All research procedures were performed in accordance with the European Directive for welfare of laboratory animals (No 86/609/EEC) and principles of good laboratory practice, approved by the Ethics Committee of the Faculty of Medical Sciences, University of Kragujevac, Kragujevac, Serbia.

\section{Biochemical assays}

The following oxidative stress parameters were determined spectrophotometrically (Shimadzu UV 1800, Japan) using collected samples of the coronary venous effluent: the index of lipid peroxidation, measured as thiobarbituric acid-reactive substances (TBARS); and levels of superoxide anion radical $\left(\mathrm{O}_{2}^{-}\right)$, hydrogen peroxide $\left(\mathrm{H}_{2} \mathrm{O}_{2}\right)$ and nitrite $\left(\mathrm{NO}_{2}^{-}\right)$.

\section{TBARS determination (index of lipid peroxidation)}

The degree of lipid peroxidation in the coronary venous effluent was estimated by measuring TBARS, using $1 \%$ thiobarbituric acid in
$0.05 \mathrm{NaOH}$, which was incubated with the coronary effluent at $100^{\circ} \mathrm{C}$ for $15 \mathrm{~min}$ and measured at $530 \mathrm{~nm}$. Krebs-Henseleit solution was used as a blank probe (22).

Determination of $\mathrm{NO}_{2}{ }^{-}$level

NO decomposes rapidly to form stable nitrite/nitrate products. The $\mathrm{NO}_{2}^{-}$level was measured and used as an index of $\mathrm{NO}$ production, using Griess's reagent. A total of $0.5 \mathrm{~mL}$ of perfusate was precipitated with $200 \mu \mathrm{L}$ of $30 \%$ sulphosalicylic acid, vortexed for $30 \mathrm{~min}$ and centrifuged at $3000 \times g$. Equal volumes of the supernatant and Griess's reagent (containing $1 \%$ sulphanilamide in $5 \%$ phosphoric acid $/ 0.1 \%$ naphthalene ethylenediamine-dihydrochloride) were added, incubated for $10 \mathrm{~min}$ in the dark and measured at $543 \mathrm{~nm} . \mathrm{NO}_{2}{ }^{-}$levels were calculated using sodium nitrite as the standard (23).

Determination of superoxide anion radical level

$\mathrm{O}_{2}^{-}$levels were measured at $530 \mathrm{~nm}$ via a nitro blue tetrazolium reaction in TRIS buffer with coronary venous effluent. Krebs-Henseleit solution was used as a blank probe (24).

\section{Determination of $\mathrm{H}_{2} \mathrm{O}_{2}$ level}

The measurement of $\mathrm{H}_{2} \mathrm{O}_{2}$ was based on the oxidation of phenol red by $\mathrm{H}_{2} \mathrm{O}_{2}$ in a reaction catalyzed by horseradish peroxidase (25). Two hundred microlitres of perfusate was precipitated using $800 \mathrm{~mL}$ of freshly prepared phenol red solution; $10 \mu \mathrm{L}$ of $(1: 20)$ horseradish peroxidase (made immediately before use) was subsequently added. For the blank probe, an adequate volume of Krebs-Henseleit solution was used instead of coronary venous effluent. The level of $\mathrm{H}_{2} \mathrm{O}_{2}$ was measured at $610 \mathrm{~nm}$.

\section{Drugs}

All drugs used in the experimental protocol were obtained from Sigma-Aldrich (USA).

\section{Statistical analysis}

Data are reported as mean \pm SE. Paired $t$ tests were used in statistical analysis; $\mathrm{P}<0.05$ was considered to be statistically significant.

\section{RESULTS}

The effects of glycine on cardiodynamics, CF and oxidative stress (Figure 1, Figure 2)

Treatment with glycine did not lead to statistically significant changes in any of the measured cardiodynamic parameters or oxidative stress markers.

\section{The effects of glutamate on cardiodynamics, CF and oxidative} stress (Figure 1, Figure 2)

Similar to the previous case, after treatment with glutamate, there were no significant changes in values of cardiodynamic and oxidative stress parameters.

\section{The effects of the combined application of glycine and glutamate on cardiodynamics, CF and oxidative stress}

Treatment with a combination of glycine and glutamate induced a significant decrease in $\mathrm{dp} / \mathrm{dt} \max (\mathrm{P}<0.05), \mathrm{dp} / \mathrm{dt} \min (\mathrm{P}<0.05), \mathrm{HR}$ $(\mathrm{P}<0.01)$ and $\mathrm{CF}(\mathrm{P}<0.05)$ compared with the control conditions (Figure 1). During the washout period, all parameters reached their control values; thus, there was no significant difference between control values and values after the washout period (Figure 1). The combined administration of glycine and glutamate caused a statistically significant increase in $\mathrm{NO}_{2}^{-}(\mathrm{P}<0.05), \mathrm{O}_{2}^{-}(\mathrm{P}<0.05)$ and $\mathrm{H}_{2} \mathrm{O}_{2}(\mathrm{P}<0.05)$ (Figure 2). Similar to cardiodynamic parameters and $\mathrm{CF}$, all changed values of oxidative stress biomarkers returned to values that are not significantly different from control (Figure 2).

\section{DISCUSSION}

The aim of the present study was to asses the effects of glycine, glutamate and their combination on cardiac function, CF and oxidative 
stress in isolated rat heart, and to examine the effects of potential activation of NMDA receptors in isolated rat hearts.

Treatment with glycine at a concentration of $100 \mu \mathrm{mol} / \mathrm{L}$ did not significantly affect any observed cardiodynamic parameter or CF (Figure 1). Some authors have observed beneficial effects of glycine on the cardiovascular system (26-28). Wang et al (26) explained this effect of glycine by the activation of glycine-gated chloride channels in cardiomyocytes, which results in prevention of excessive accumulation of $\mathrm{Ca}^{2+}$. The lack of a positive effect of glycine in our study may be a consequence of the small dose used; Wang et al (26) used a dose of $2 \mathrm{mmol} / \mathrm{L}$ glycine compared with $100 \mu \mathrm{mol} / \mathrm{L}$ in our study. Furthermore, Zhong et al (29) noted the cytoprotective effect of glycine and proposed that glycine may act as an important cytoprotective agent in prevention of early myocardial ischemiareperfusion injury (29). In this study, glycine, applied in a dose of $0.5 \mathrm{mg} / \mathrm{g}$ body weight, reduced the infarct size by $21 \%$ when rats were subsequently subjected to cardiac ischemia-reperfusion injury; this effect was due to a reduction in cardiomyocyte apoptosis, blunted activation of p38 MAP kinase and JNK, and decreased Fas ligand expression. Glycine also may have antioxidant activity - it is a precursor in the synthesis of several compounds (creatine, nucleic acid, heme) but, more importantly, glycine contributes to the generation of glutathione (c-glutamylcysteinylglycine), which is a crucial intracellular antioxidant (30). The absence of changes in values of oxidative stress markers (Figure 2) observed in the present study may be a consequence of a short period of glycine exposure, thus leaving little chance for glutathione composition.

Similar to the case of glycine administration, treatment with glutamate (at a concentration of $100 \mu \mathrm{mol} / \mathrm{L}$ ) did not cause any significant modification of any observed cardiodynamic parameter of CF (Figure 1). Glutamate is the major excitatory neurotransmitter in the CNS, and it is a cause of excitotoxicity that is closely related to many neurological disorders (31-33). However, the role of glutamate and glutamate receptors in regulation of heart function or in the development of cardiovascular diseases remains unclear. Sun et al (34) have investigated the role of glutamate in ischemia-reperfusion-induced arrhythmias. Their results revealed a significant increase in serum glutamate levels induced by ischemia-reperfusion, as well as a higher frequency of ventricular arrhythmias. Improvement of these disorders, as well as improvement of SERCA2a expression and sarcoplasmic reticulum $\mathrm{Ca}^{2+}$-ATPase activity, was achieved by applying MK-801 (a noncompetitive NMDA receptor antagonist) and gabapentin (a glutamate release inhibitor).

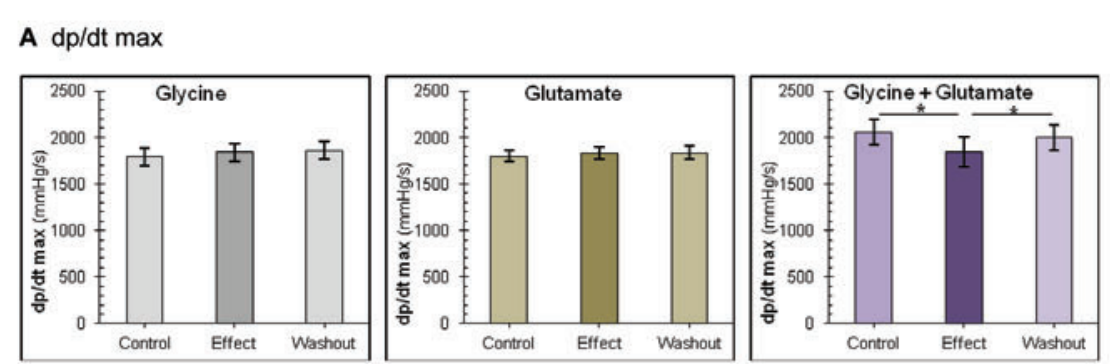

\section{B dp/dt min}
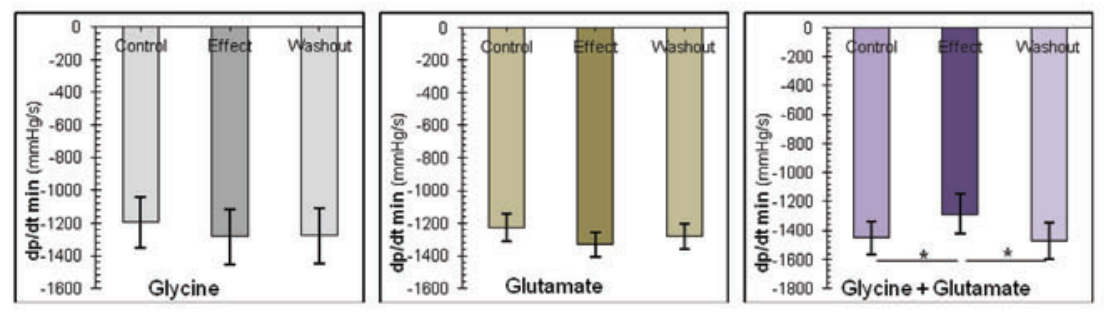

\section{SLVP}
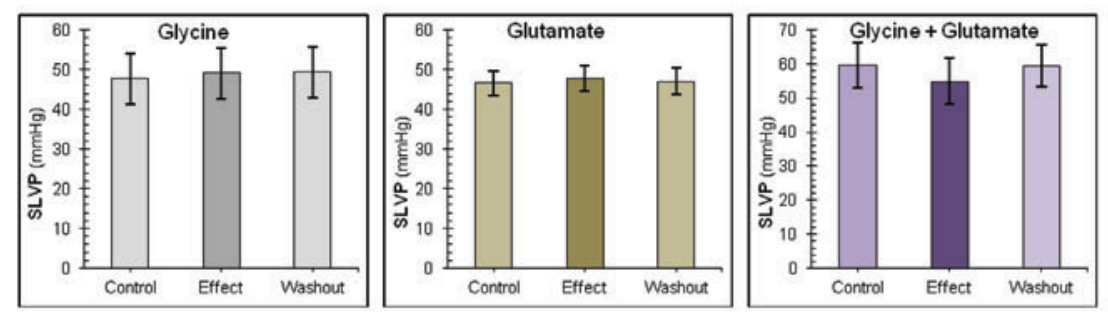

\section{DLVP}
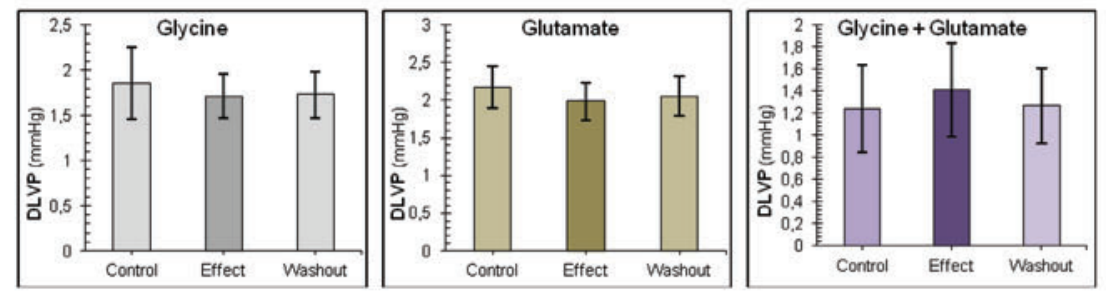

\section{E Heart rate}
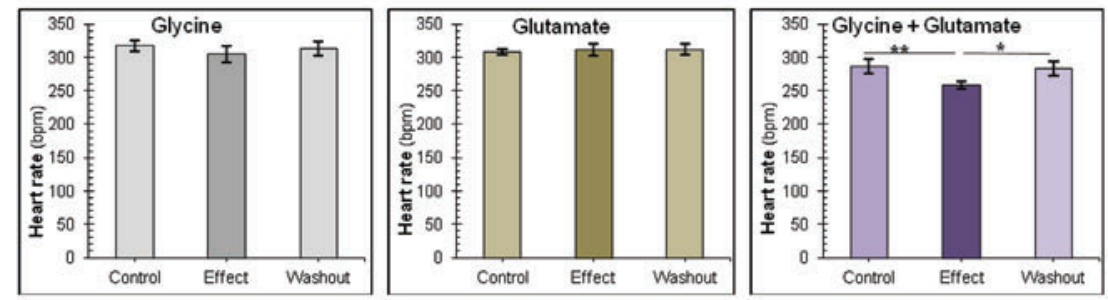

\section{F Coronary flow}


Figure 1) Effects of glycine, glutamate and their combined application on cardiodynamic parameters and coronary flow of isolated rat heart. Data expressed as mean \pm SE. $* P<0.05 ; * * P<0.001$. DLVP Diastolic left ventricular pressure; $d p / d t$ max Maximum rate of pressure development in the left ventricle; $d p / d t$ min Minimum rate of pressure development in the left ventricle; SLVP Systolic left ventricular pressure 


\section{A TBARS}
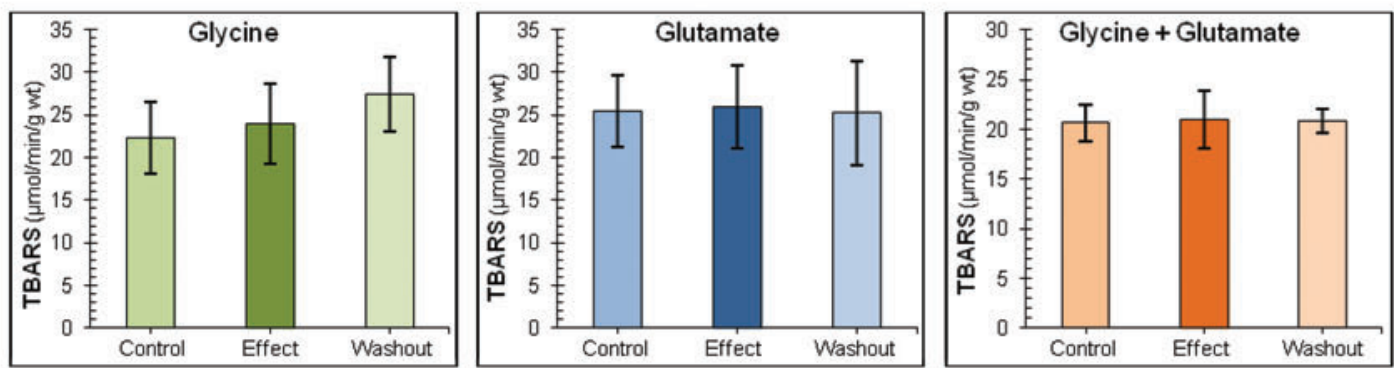

B Nitrites $\left(\mathrm{NO}_{2}^{-}\right)$
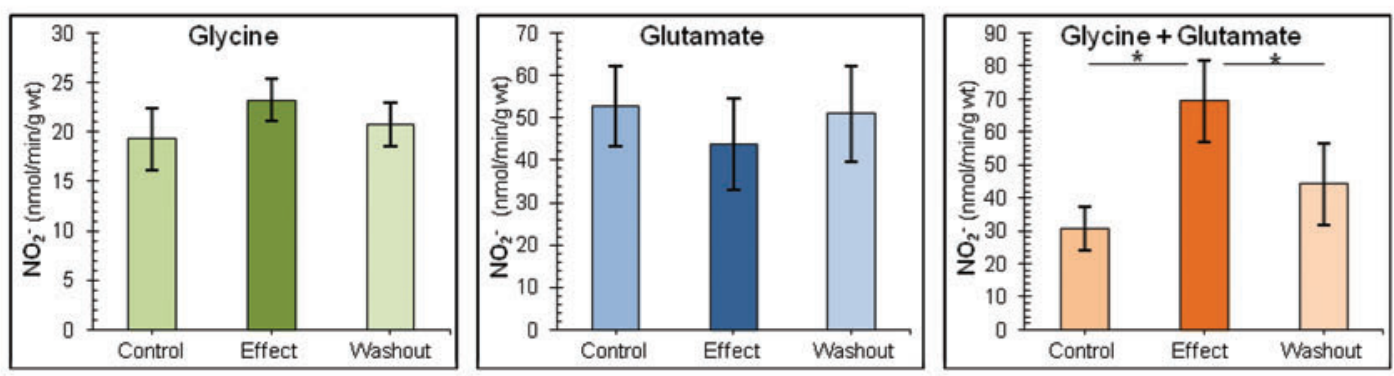

\section{Superoxide anion radical $\left(\mathrm{O}_{2}^{-}\right)$}
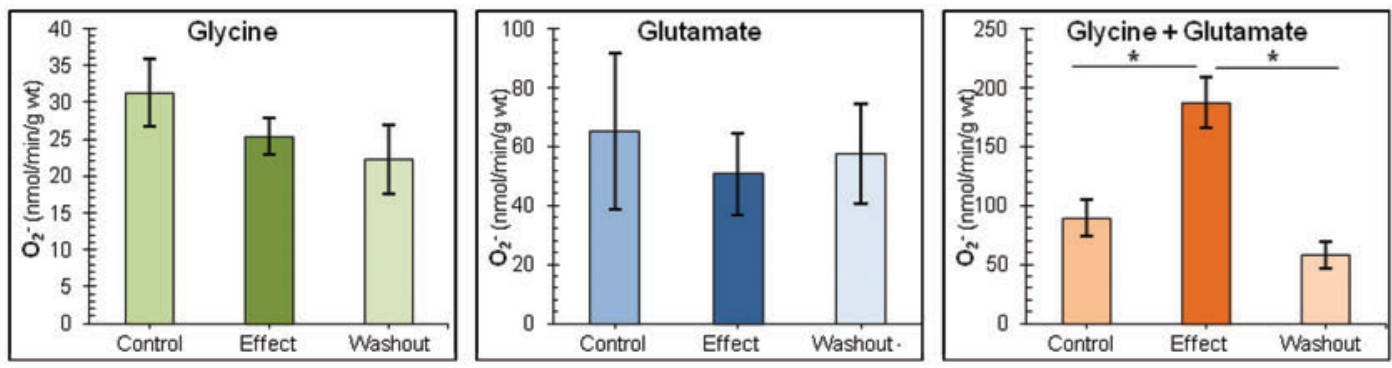

\section{Hydrogen peroxide $\left(\mathrm{H}_{2} \mathrm{O}_{2}\right)$}
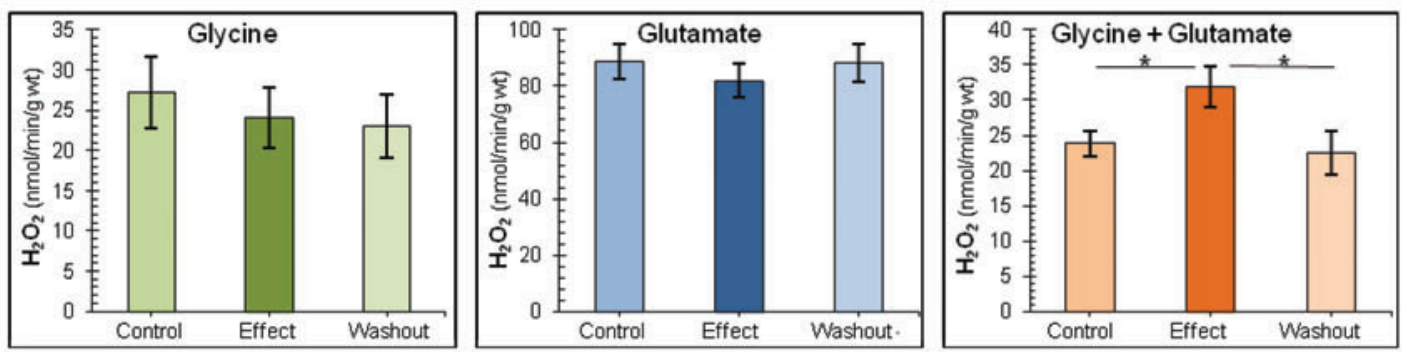

Figure 2) Effects of glycine, glutamate and their combined application on biomarkers of oxidative stress in isolated rat heart. Data are presented as mean \pm SE. $* P<0.05 ; * * P<0.001$. TBARS Thiobarbituric acid-reactive substances

The authors suggested that glutamate mediates reperfusion arrhythmias and that underlining mechanism is due to $\mathrm{Ca}^{2+}$ overload via NMDA receptors. The abovementioned studies were conducted in vivo; thus, glycine (required for activation of NMDA receptors) was likely present in sufficient amounts in the tissue.

The combined use of glycine and glutamate induced significant decreases in $\mathrm{dp} / \mathrm{dt}$ max and $\mathrm{dp} / \mathrm{dt}$ min, parameters that reflect cardiac contractility (Figure $1 \mathrm{~A}$ and $1 \mathrm{~B}$ ). In their study, Tyagi et al (35) investigated the effect of cardiac-specific deletion of the NMDA receptor on mitochondrial matrix metalloproteinase9-mediated autophagy/mitophagy in hyperhomocysteinemia. Their results showed that cardiac-specific deletion of NMDA receptors ameliorates homocysteine-induced decline of cardiomyocyte contractility; ie, they assumed that reduction of cardiomyocyte contractility was partially due to increased activation of mitochondrial matrix metalloproteinase- 9 with the degradation of connexin-43 as well as oxidative stress. Moshal et al (36) investigated the influence of hyperhomocysteinemia on cardiac myocytes and showed that homocysteine induced an increased expression of NMDA receptor in ventricular myocytes. Because homocysteine is considered to exert its negative effects through NMDA receptor activation, and because our results are similar to those of previously mentioned studies, it is possible that the underlying mechanism is the same. In the abovementioned study by Sun et al (34), the authors noted that increased levels of serum 
glutamate in in vivo induced myocardial infarction also caused an increase of intracellular $\mathrm{Ca}^{2+}$, which was prevented by NMDA receptor blocking by MK-801. Taking into account our experimental model, it is likely that simultaneous application of both NMDA receptor coagonists was necessary for receptor activation and the manifestation of adverse effects on myocardial contractility.

The combined administration of glycine and glutamate did not affect either systolic or diastolic pressure in the left ventricle (Figure 1C and 1D). There are insufficient available studies investigating the role of glutamate receptors in the heart in the regulation of blood pressure. However, some authors have investigated the influence of modulation of glutamate receptors in specific parts of nervous system on blood pressure. Santini et al (37) showed that administration of L-glutamate in the ventral hippocampus evokes dose-dependent pressor and tachycardiac responses, which were abolished by pretreatment with an NMDA receptor antagonist, selective neuronal NOS inhibitor, NO scavenger and guanylate cyclase inhibitor. Their results indicate that L-glutamate affects blood pressure by interaction with NMDA receptors $\mathrm{NO}$ and guanylate cyclase in the CNS. They also showed that the activation of NMDA receptors in the CNS leads to a marked activation of the cardiac sympathetic nervous system.

Coapplication of glycine and glutamate induced a significant decrease in HR (Figure 1E). Liu et al (38) investigated the impact of monosodium L-glutamate on HR and tachyarrhythmias in normal and myocardial infarcted rats in vivo. Monosodium L-glutamate induced bradycardia in normal rats and lethal tachyarrhythmias in rats with myocardial infarction, which were prevented by blocking the AMPA and NMDA receptors. The absence of bradycardia in the group of hearts treated with glutamate only in our study may be due to the lack of glycine, which is required for the activation of NMDA receptors. In the study by Liu et al (38), this was avoided because the study was conducted in vivo.

Simultaneous application of glycine and glutamate significantly decreased CF (Figure $1 F$ ). In the CNS, activation of NMDA receptors is linked with the dilation of blood vessels $(38,39)$. NMDA receptors mediate the dilation of brain arterioles resulting from the activation of neuronal NOS in neurons and production of NO (39). Considering that calcium homeostasis is of crucial importance for heart function, activation of NMDA receptors could induce reduction in CF by accumulation in vascular smooth muscle cells in coronary arteries. Namely, NMDA receptors were detected in rat vascular smooth muscle, and its activation by homocysteine appears to provoke vascular smooth muscle cell migration and/or proliferation and dysregulation of vascular smooth muscle cell functions (40).

Glycine and glutamate in combination induced statistically significant increases in $\mathrm{NO}_{2}^{-}, \mathrm{O}_{2}^{-}$and $\mathrm{H}_{2} \mathrm{O}_{2}$, and all biomarkers of oxidative stress reached values near controls after the washout period (Figure 2B, 2C, 2D). Hama-Tomioka et al (39) showed that application of NMDA (NMDA receptor agonist) induced production of $\mathrm{O}_{2}^{-}$and $\mathrm{NO}$ within brain parenchymal arterioles. Gao et al (18) have also demonstrated that activation of the NMDA receptor induces the increased production of reactive oxygen species in cultured rat cardiomyocytes, which was $\mathrm{Ca}^{2+}$-dependent. Furthermore, these authors noted that application of $\mathrm{N}$-acetylcystein (NAC), which has antioxidant properties, can prevent adverse effects of NMDA receptor overstimulation. Their results suggested that NAC may prevent the glutamate-induced apoptosis of cultured rat cardiomyocytes and, in this manner, potentially prevent reduction of myocardial function. Experiments with isolated brain mitochondria revealed a significant increase in $\mathrm{H}_{2} \mathrm{O}_{2}$ production induced by glutamate, which were prevented by MK-801 (NMDA receptor antagonist) (41). The proposed underlying mechanism for increased $\mathrm{NO}_{2}^{-}$levels, which mirror $\mathrm{NO}$ production, is activation of NOS and NADPH oxidase (38). Hama-Tomioka et al (39) also noted the link between increased $\mathrm{O}_{2}^{-}$production and activation of NOX2 (NADPH oxidase subunit) by NMDA receptors. Also, $\mathrm{Ca}^{2+}$ overload due to NMDA receptor activation induce increased $\mathrm{H}_{2} \mathrm{O}_{2}$ production in complex I, III and II (41). The lack of a vasodilatory effect of $\mathrm{NO}$ in our study could be the consequence of conversion of $\mathrm{NO}$ and $\mathrm{O}_{2}^{-}$to peroxynitrite, which is one of free radicals with most potent deleterious effect and could mediate the adverse effects of NMDA stimulation by glycine and glutamate $(42,43)$.

Overall, the results of the present study indicate that prevention of NMDA receptor activation may have a positive effect in conditions such as hyperhomocysteinemia (because homocysteine exerts its undesirable effects by activation of the NMDA receptor [35]), or ischemia (because there is an increase in the concentration of glutamate after myocardial infarction [34] and ischemic stroke [44]).

\section{CONCLUSION}

Data collected from the present investigation could help in better understanding the role of NMDA receptors in cardiovascular (patho) physiology. The results of the present study indicate that NMDA receptors likely have an important role in function of the heart and coronary circulation. Also, our results suggest that the damaging effect of NMDA receptors overstimulation in the heart may be mediated by oxidative stress.

ACKNOWLEDGEMENTS: This project was supported by Grant no. 175043 from the Ministry of Science and Technical Development of the Republic of Serbia, and the Junior Project 04/2011, Faculty of Medical Sciences, University of Kragujevac, Serbia.

DISCLOSURES: None of the authors of this study has any actual or potential conflicts of interest to disclose, including financial, personal or other relationships with specific persons or organizations.

\section{REFERENCES}

1. Vyklicky V, Korinek M, Smejkalova T, et al. Structure, function, and pharmacology of NMDA receptor channels. Physiol Res 2014;63:191-203.

2. Ulbrich MH, Isacoff EY. Rules of engagement for NMDA receptor subunits. Proc Natl Acad Sci U S A 2008;105:14163-8.

3. Clements JD, Westbrook GL. Activation kinetics reveal the number of glutamate and glycine binding sites on the $N$-methyl-Daspartate receptor. Neuron 1991;7:605-13.

4. Chatterton JE, Awobuluyi M, Premkumar LS, et al. Excitatory glycine receptors containing the NR3 family of NMDA receptor subunits. Nature 2002;415:793-8.

5. Mayer ML, Westbrook GL. Permeation and block of $\mathrm{N}$-methyl-D-aspartic acid receptor channels by divalent cations in mouse cultured central neurones. J Physiol 1987;394:501-27.

6. Kehoe LA, Bernardinelli Y, Muller D. GluN3A: An NMDA receptor subunit with exquisite properties and functions. Neural Plast 2013;2013:145387.

7. Black SA, Stys PK, Zamponi GW, Tsutsui S. Cellular prion protein and NMDA receptor modulation: Protecting against excitotoxicity. Front Cell Dev Biol 2014;28:2-45.

8. Zhou Q, Sheng M. NMDA receptors in nervous system diseases. Neuropharmacology 2013;74:69-75.

9. Parsons MP, Raymond LA. Extrasynaptic NMDA receptor involvement in central nervous system disorders. Neuron 2014;82:279-93.

10. Gill SS, Pulido OM, Mueller RW, McGuire PF. Molecular and immunochemical characterization of the ionotropic glutamate receptors in the rat heart. Brain Res Bull 1998;46:429-34.

11. Seeber S, Humeny A, Herkert M, Rau T, Eschenhagen T, Becker CM. Formation of molecular complexes by $N$-methyl-Daspartate receptor subunit NR2B and ryanodine receptor 2 in neonatal rat myocard. J Biol Chem 2004;279:21062-8.

12. Huang CF, Su MJ. Positive inotropic action of NMDA receptor antagonist (+)-MK801 in rat heart. J Biomed Sci 1999;6:387-98. 
13. Krainc D, Bai G, Okamoto S, et al. Synergistic activation of the $\mathrm{N}$-methyl-D-aspartate receptor subunit 1 promoter by myocyte enhancer factor 2C and Sp1. J Biol Chem 1998;273:26218-24.

14. LeMaistre JL, Sanders SA, Stobart MJ, et al. Coactivation of NMDA receptors by glutamate and D-serine induces dilation of isolated middle cerebral arteries. J Cereb Blood Flow Metab 2012;32:537-47.

15. Said SI, Berisha HI, Pakbaz H. Excitotoxicity in the lung: N-methyl$\mathrm{D}$-aspartate-induced, nitric oxide-dependent, pulmonary edema is attenuated by vasoactive intestinal peptide and by inhibitors of poly(ADP-ribose) polymerase. Proc Natl Acad Sci U S A 1996;93:4688-92.

16. Qureshi I, Chen H, Brown AT, et al. Homocysteine-induced vascular dysregulation is mediated by the NMDA receptor. Vasc Med 2005;10:215-23.

17. McGee MA, Abdel-Rahman AA. Enhanced vascular neuronal nitric-oxide synthase-derived nitric-oxide production underlies the pressor response caused by peripheral $\mathrm{N}$-methyl-D-aspartate receptor activation in conscious rats. J Pharmacol Exp Ther 2012:342:461-71.

18. Gao X, Xu X, Pang J, et al. NMDA receptor activation induces mitochondrial dysfunction, oxidative stress and apoptosis in cultured neonatal rat cardiomyocytes. Physiol Res 2007;56:559-69.

19. Quincozes-Santos A, Bobermin LD, Tramontina AC, et al. Oxidative stress mediated by NMDA, AMPA/KA channels in acute hippocampal slices: Neuroprotective effect of resveratrol. Toxicol In Vitro 2014;28:544-51.

20. Tyagi N, Mishra PK, Tyagi SC. Homocysteine, hydrogen sulfide $\left(\mathrm{H}_{2} \mathrm{~S}\right)$ and NMDA-receptor in heart failure. Indian J Biochem Biophys 2009;46:441-6.

21. Pall ML. The NO/ONOO-cycle as the central cause of heart failure. Int J Mol Sci 2013;14:22274-330.

22. Ohkawa H, Ohishi N, Yagi K. Assay for lipid peroxides in animal tissues by thiobarbituric acid reaction. Anal Biochem 1979;95:351-8.

23. Green LC, Wagner DA, Glogowski J, Skipper PL, Wishnok JS, Tannenbaum SR. Analysis of nitrate, nitrite, and [15N]nitrate in biological fluids. Anal Biochem 1982;126:131-8.

24. Auclair C, Voisin E. Nitroblue tetrazolium reduction. In: Greenvvald RA, ed. Handbook of Methods for Oxygen Radical Research. Boca Raton: CRC Press, 1985:123-32.

25. Pick E, Keisari Y. A simple colorimetric method for the measurement of hydrogen peroxide produced by cells in culture. J Immunol Methods 1980;38:161-70.

26. Wang HD, LüXX, Lu DX, et al. Glycine inhibits the LPS-induced increase in cytosolic $\mathrm{Ca}^{2+}$ concentration and TNFalpha production in cardiomyocytes by activating a glycine receptor. Acta Pharmacol Sin 2009;30:1107-14.

27. McCarty MF, Barroso-Aranda J, Contreras F. The hyperpolarizing impact of glycine on endothelial cells may be anti-atherogenic. Med Hypotheses 2009;73:263-4.

28. McCarty MF, DiNicolantonio JJ. The cardiometabolic benefits of glycine: Is glycine an 'antidote' to dietary fructose? Open Heart 2014 28;1:e000103.
29. Zhong X, Li X, Qian L, et al. Glycine attenuates myocardial ischemia-reperfusion injury by inhibiting myocardial apoptosis in rats. J Biomed Res 2012;26:346-54.

30. Sekhar RV, Patel SG, Guthikonda AP, et al. Deficient synthesis of glutathione underlies oxidative stress in aging and can be corrected by dietary cysteine and glycine supplementation. Am J Clin Nutr 2011;94:847-53.

31. Horak M, Petralia RS, Kaniakova M, Sans N. ER to synapse trafficking of NMDA receptors. Front Cell Neurosci 2014;8:394.

32. El-Ansary A, Al-Ayadhi L. GABAergic/glutamatergic imbalance relative to excessive neuroinflammation in autism spectrum disorders. J Neuroinflammation 2014;11:189.

33. Doble A. The role of excitotoxicity in neurodegenerative disease: Implications for therapy. Pharmacol Ther 1999;81:163-221.

34. Sun X, Zhong J, Wang D, et al. Increasing glutamate promotes ischemia-reperfusion-induced ventricular arrhythmias in rats in vivo. Pharmacology 2014;93:4-9.

35. Tyagi N, Vacek JC, Givvimani S, Sen U, Tyagi SC. Cardiac specific deletion of $\mathrm{N}$-methyl-d-aspartate receptor 1 ameliorates mtMMP-9 mediated autophagy/mitophagy in hyperhomocysteinemia. J Recept Signal Transduct Res 2010;30:78-87.

36. Moshal KS, Tipparaju SM, Vacek TP, et al. Mitochondrial matrix metalloproteinase activation decreases myocyte contractility in hyperhomocysteinemia. Am J Physiol Heart Circ Physiol 2008;295:890-7.

37. Santini CO, Fassini A, Scopinho AA, Busnardo C, Corrêa FM, Resstel LB. The ventral hippocampus NMDA receptor/nitric oxide/ guanylate cyclase pathway modulates cardiovascular responses in rats. Auton Neurosci 2013;177:244-52.

38. Girouard H, Wang G, Gallo EF, et al. NMDA receptor activation increases free radical production through nitric oxide and NOX2. J Neurosci 2009;29:2545-52.

39. Hama-Tomioka K, Kinoshita H, Nakahata K, et al. Roles of neuronal nitric oxide synthase, oxidative stress, and propofol in $\mathrm{N}$-methyl-D-aspartate-induced dilatation of cerebral arterioles. Br J Anaesth 2012;108:21-9.

40. Qureshi I, Chen H, Brown AT, et al. Homocysteine-induced vascular dysregulation is mediated by the NMDA receptor. Vasc Med 2005;10:215-23

41. Lobysheva NV, Selin AA, Vangeli IM, Byvshev IM, Yaguzhinsky LS, Nartsissov YR. Glutamate induces $\mathrm{H}_{2} \mathrm{O}_{2}$ synthesis in nonsynaptic brain mitochondria. Free Radic Biol Med 2013;65:428-35.

42. Beckman JS, Crow JP. Pathological implications of nitric oxide, superoxide and peroxynitrite formation. Biochem Soc Trans 1993;21:330-4

43. Ma S, Zhang Z, Yi F, et al. Protective effects of low-frequency magnetic fields on cardiomyocytes from ischemia reperfusion injury via $\mathrm{ROS}$ and NO/ONOO-. Oxid Med Cell Longev 2013;2013:529173.

44. Yan G, Dai Z, Xuan Y, Wu R. Early metabolic changes following ischemia onset in rats: An in vivo diffusion-weighted imaging and $1 \mathrm{H}$-magnetic resonance spectroscopy study at 7.0 T. Mol Med Rep 2015;11:4109-14. 